\title{
Model of Indonesia-Timor Leste Land Border Management by Optimizing the Cross-Border Post in Belu Regency, East Nusa Tenggara
}

\author{
Iva Rachmawati \& Fauzan
}

Universitas Pembangunan Nasional "Veteran” Yogyakarta

\begin{abstract}
This article is based on our research on the management of Cross-Border Posts (CBPs) in Belu that was conducted in three Cross Border Posts: Mota'ain, Motamasin and Turiskain. We offer a model of CBP management with two changes to the initial function design embedded with CBP (CIQS/Custom, Immigration, Quarantine and Security). The changes we offer are: (1) withdrawing the military personnel; and (2) assigning a new social function. These changes are based on the facts of local's historical, social and economic backgrounds which are different from those of other areas. This approach will absolutely affect the form of the current CBP. Interviews were conducted to collect information related to the socio-cultural backgrounds and economic needs among the people living around the border. With the changes in mind, functions, it is expected that the CBP can meet the need of the people living around the border.
\end{abstract}

Key words: cross border post function reform, military withdrawal, social function.

Artikel ini merupakan hasil dari penelitian kami mengenai pengelolaan Pos Lintas Batas (PLB) di Belu yang dilakukan atas tiga PLB yaitu Mota'ain, Motamasin dan Turiskain. Kami mengusulkan sebuah pengelolaan PLB dengan dua perubahan penting yang ada di dalam fungsi lama PLB (CIQS/Custom, Immigration, Quarantine and Security). Perubahan yang kami usulkan adalah: (1) ditariknya personel militer dari PLB; dan (2) mengimbuhkan fungsi sosial. Perubahan yang kami usulkan ini berdasarkan pertimbangan kesejarahan, faktor sosial dan ekonomi masyarakat lokal. Metode riset yang kami lakukan adalah melalui wawancara mendalam terhadap pelaku lintas batas dan pemerintah lokal untuk mendapatkan data yang diperlukan. Perubahan dalam fungsi PLB ini diharapkan dapat memenuhi kebutuhan masyarakat lokal.

Kata-Kata Kunci: perubahan fungsi pos lintas batas, penarikan militer, fungsi sosial. 
The Indonesia - The Democratic Republic of East Timor (RDTL) border in Belu-Bobonaro is of primary importance due to the fact that until 2011 Indonesia was still the second exporter, after the USA, of some particular products to Timor Leste. In addition, the rate of border crossers at some Cross Border Posts, such as at the CBP in Mota'ain in Belu, was relatively high. In October 2011 the number of incoming border crossers reached 3,888 people and the number of outgoing border crossers was 4,495 people (based on the report from Immigration Office at Mota'ain Cross Border Post in 2011). This condition eventually requires a better border management since the rate of economic growth and development in RDLT is getting better.

Nevertheless, the shift in the paradigm of border management has not been in line with the policy makers' perception. The Cross Border Posts, which have the CIQS (Customs, Immigration, Quarantine, and Security) function, have not functioned accordingly. In many cases of Cross Border Posts in Indonesia, the function is dominated by the military (Indonesian National Armed Force). For security reasons, the number of military personnel is bigger than that of civil personnel. This is totally different from the management carried out by Timor Leste through their 'soft border regime' policy. Unfortunately, the tight security in CBP has not been able to reduce the border problems in the last few years according to Kol. I Dewa Ktut Siangan as stated in article "Postur Pertahanan Indonesia di Wilayah Perbatasan Timor Leste" (Hanoin 2011). Other problems that affect the peace stability along the border of Indonesia- Timor Leste are the existence and the handling of the exrefugees of Timor Leste since 1999. Most of the people of East Nusa Tenggara who lent their lands to the Timor Timur refugees in 1999 think that the existence of the refugees is only temporary (Wuryandari 2009, 203). From some sample cases above, it can be seen that the problems are dominated by economy and social reasons.

Thus, this research is directed to delve in-depth into the social reality and historical background in Belu-Bobonaro border area as the main foundation for the establishment of Cross Border Post.

\section{Common Problems}

Border is the line that divides the areas between/among countries, in which each country can manage its territorial sovereignty on its own. Border not only divides the areas belonging to different communities but also ensures the security of each of the area (Caflish 2006). Commonly, a border is more often viewed only from its territorial aspect. This fact often results in complicated problems when cross border posts are 
managed by merely border arrangement and agreement. Problems after problems arise and lead into an open conflict. Many conflicts arise from socio-cultural motives.

According to Kartikasari in Madu et. all (2010, 110-111), there are some problems that arise, namely (1) territorial geographic problems arising from the fact that borders of lands and seas have not been settled, (2) issues of national security and sovereignty, especially on cross border crime, (3) issues of environment, related to ecological damage and natural resource exploitation, (4) issues of poverty and underdevelopment, limited economic facilities, education, and health, (5) issues of coordination and implementation of government policy, (6) issues of demography and social change, (7) issues of patriotism and national security, especially the one dealing with the perception of people who feel that they are treated unfairly.

In a more specific research by Hariyadi (2008), it has been found out that the common problems arising at RI-RDTL border are: (1) the absence of a comprehensive regulation set that serves as governing laws in managing borders nationally or specifically that can be applied to manage RI-RDTL border; (2) the absence of an agency which specifically handles the management of the border of the two countries; (3) disparities of development between the two adjacent areas; (4) the high intensity of border crossers despite the fact that the two countries have not reached any agreement about the policy to be acted out to reduce further potential problems caused by the rate of border crossers; (5) potential interventions from certain countries on this border problem.

Based on their own virtue, each problem above can become a priority of its own to be solved, especially since there is a shift of perspective regarding how to manage a border from security approach to prosperity approach. The development of economy and other social facilities, such as education and health, as well as transportation and communication facilities must be carried out. However, it will absolutely take time. Meanwhile, the border problems such as illegal border crossers, smuggling and claims on lands need to be solved soon. Thus, Indonesia Cross Border Posts which serve to meet the needs of the people having specific characteristics are truly needed. The Cross Border Post management is part of a total effort to reorganize the exit/entry area into a country, which is currently regulated by various laws; stated at UU No. 6/2011 on Immigration, UU No. 17/2006 on Customs and UU No. 16/1992 on Quarantine of Animal, Fish, and Plant.

Cross Border Post is an "institution" established by a country at a border area in order to be able to supervise all activities conducted at the border area. It is established to ensure that there will neither be any sovereignty 
violation, nor other problems which may harm the two neighboring countries. Yet, sometimes the role of Cross-Border Post is merely as a country representative, acting only for its own sake and neglecting the condition and need of the people at the border. Some people think that this type of Cross-Border Post is the sub-concept of Integrated Border Management, namely One Stop Border Post or OSBP. Nevertheless, sometimes this term is often assumed to be the same as CBM (Coordinated Border Management) or IBM (Integrated Border Management). IBM is the organization and supervision of border agency activities to meet the common challenge of facilitating the movement of legitimate people and goods while maintaining secure borders and meeting national legal requirements (Aniszewski 2009). In this view, without any negligence on the security factor and applicable law, the main consideration is the needs of the border crossers. Meanwhile, other views emphasize the importance of cooperation and coordination in managing the institution and World Custom Union (WCO) calls it as Coordinated Border Management (Polner 2011; Pathak 2011).

\section{Border Model}

This model stems from the social and cultural considerations of the people living in the border land along with the economic interactions in the area. Those living in the border area of Indonesia RDT, more specifically in Belu and Bobonaro, share historical and kinship closeness. In fact, both were from the same origin before the arrival of Dutch and Portuguese. Those who live in this area were believed to come from Melus Tribe or "Emafatuk oan ema ai oan" (those inhabiting stones and woods). This area was once a transit area of Malays and it was believed that Belu people were Malays by blood. Those coming and live in Belu were in fact from "Sina Mutin Malaka". They came from Malaka and mingled with the Melus. In local mythology, they managed to rule through their descendants (Kementrian Dalam Negeri 2012). Another research by Correa (1994) also reveals that Timor Island inhabitants are Proto-Malays, Deutero-Malays, Melanesoide, and Vedo-Australoid. However, he concludes that they are mostly dominated by Proto-Malays or the Indonesian type. In his opinion, these people are unique, for they do not share similarities with the Papuans neither Malays ("History of Timor" t.t). This could have been because of the mixing of Melu origins and the immigrants million years ago as understood by the people. This is also confirmed by Fox that Malay-type migrants establish themselves on Timor's central-north coast in a long process beginning around 3,000 $\mathrm{BC}$ before moving inland and displacing and dominating the frizzyhaired "Melanesian" Antoni or "people of the dry land". The migration of Malaka people to this land was triggered by commerce that was once 
dominated by commodities such as cendana (sandalwood) and bee nests, the same reasons that had attracted traders coming from China.

As explained by Nordholt ("History of Timor". t.t), Belu people were an open community. They were united by a centralized authority that guaranteed their welfare; an authority responsible to make public and ritual decisions. Therefore, the kinship of the people of Timor Island is in fact very close. Fox in "History of Timor" (nd), stated that the influence of Belu Kingdom around Wehale is almost 2/3 of the whole island. Their closeness is based on their belief not only that they are of the same descendants or through marriages but also that they are united by the relatively same language, Tetum Belu and Tetum Terik. From the language point of view, the linguistic mapping shows that along the border of Indonesia and Timor Leste, people use the same language. This in fact makes communication easier that in turn will facilitate trading, social interactions, and emotional closeness. The map indicates that the people along the border widely use the same languages even though they are of different tribes namely Tetun, Bunaq, and Bekais. Our interviews with the border crossers indicate that they are in fact still using the same Tetun especially those who come from Timor Leste.

\section{Picture 1. Map of Ethnolinguistic in Timor Island}

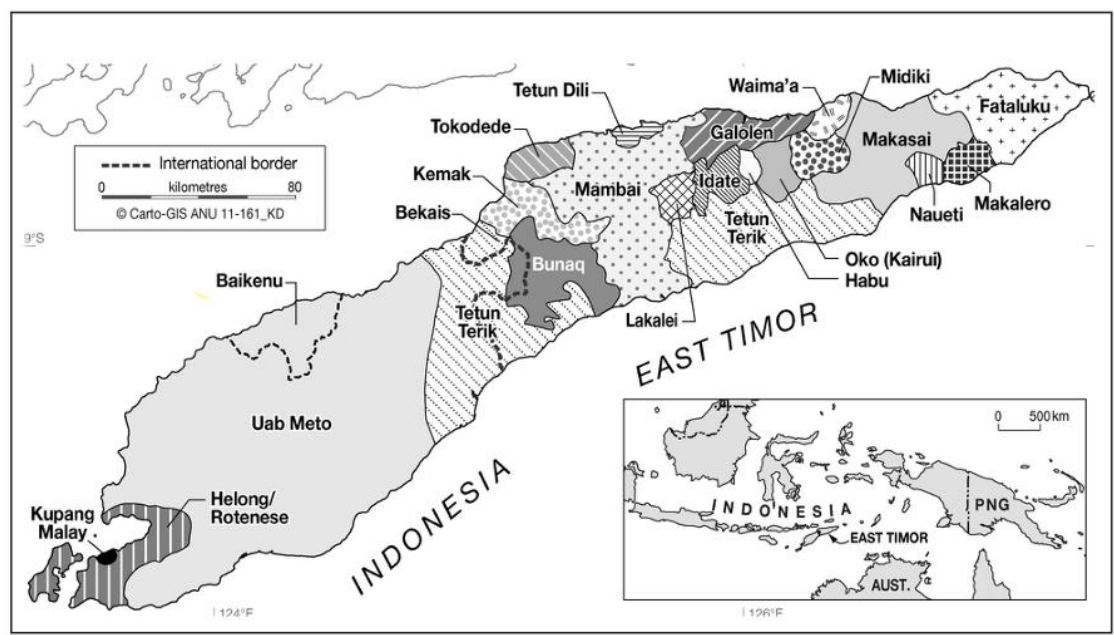

Source: Mc. William and Traube (2011)

According to some historians, the division of Belu into the North and the South was just a strategy of the Dutch and Portuguese colonial administrations to improve the system of control over the people (Kementrian Dalam Negeri 2012). The people of Timor Island, especially Belu people or Tetun speakers were increasingly split into small parts by 
the policies of the Dutch and the Portuguese that divided their territory into two in 1913, the policy of which was then endorsed by the International Court in Den Haag, popularly known as Sentenca Arbital. Through this policy, the Portuguese got the Eastern part and the Central Oecusse. This area in turn serves as the border of Indonesia and Timor Leste.

The interviews that we conducted indicate that social relations along with economic needs and education motives serve as the reasons of the border crossing. Several respondents in Motamasin and Mota'ain revealed that they cross the border to visit their relatives (Interviews with border crossers, 20-26 August 2013). They mostly live in Silawan or Atambua dan still have relatives in Timor Leste. Frequently, people also cross the border to attend such ceremonies as weddings as carried out by one of the respondents who crossed Mota'ain to attend his sister in law's wedding (interviews with border crossers, 20-26 August 2013). Another respondent crossed with the intention to attend a traditional ritual celebration of a wedding; meanwhile two respondents did it to attend a tradition of a funeral event in Timor Leste. The same practice was also found among the Timor Lestes. Two respondents crossed the border at Motamasin to attend a ritual celebration or other traditional ritual events. Interestingly, there was a military personnel who crossed the border for a family visit stating that he was the chief of a traditional community in Timor Leste (Interviews with border crossers, 20-26 August 2013).

The fact that borderline inhabitants cross the border because of kinship as the primary motive and other different motives is interesting. This fact can be traced back to what was said by some citizens of Timor Leste, those that currently are studying in one of the universities in East Java (interviews with border crossers, 20-26 August 2013). There are also such other motives such as searching for jobs (interviews with border crossers, 20-26 August 2013).

Kinship reasons are then found to be responsible for illegal cross border trade. A trader of lemongrass oil and eucalyptus oil from the village of Silawan stated, "There are (my) families that sell the stuff here and there are also ones who sell the stuff there. There are those who live here and also those who live there." (interviews with border crossers, 20-26 August 2013). Meanwhile, one of the Village Chief in the region stated, "There is one thing that should be understood. The trade between people of Indonesia and those of Timor Leste is not only because of economic needs but also because of emotion and kinship. So, if there are families that need gasoline there, I don't think that it is wrong to send some there." (Interviews with border crossers, 20-26 August 2013). Illegal trading widely happens along the border. Sometimes, they have to pay 5 
Dollars to the officers on duty to be allowed to cross the border without having to submit a document and then go via an illegal pathway as commonly found along the border (an unrecorded interview).

The interviews indicate that the people are forced to run illegal trading because they need to make the ends met; that is for daily needs and school tuitions. A mother from Silawan stated that she practiced illegal trading due to some urgent needs and that she does not have a job. To make it worse, she does not have any land to cultivate (interviews with border crossers, 20-26 August 2013). The same was stated by several respondents saying, "People know that there is a regulation in Siwalan. But, the people have nothing at all. No land. And, their children need schooling. It is expensive just to go to the elementary school. There are students with no schooling." (Interviews with border crossers, 20-26 August 2013).

A village chief in Silawan confirmed the statement by saying, "It's true. First, it is for the basic needs of the family economy. Secondly, they dare do it because there is an opportunity; an opportunity to do it." (Interviews with border crossers, 20-26 August 2013). He also explained that the people hardly make the ends met; no job, no land. The haves have bought their land in Silawan. The Siwalans then do not have land to grow crops. The absence of market around the border also makes them trade secretly. They have to sell goods to Timor Leste and it means that they have to take the legal way using passport or border crossing pass. This, for most of the people, is expensive and even needs more money to get it (interviews with border crossers, 20-26 August 2013).

If the 3 districts around the border, we observed the decrease of such produce as rice and other crops. This decrease is concomitant with the decrease of productive land in the 3 areas-samples of 2000-2011. According to "Tasifeto Timur dalam Angka", in the district of East Tasifeto the yield of rice of 2007 was 2,832 tons, and it decreased to 175 tons in 2011 (Badan Pusat Statistik Kabupaten Belu 2012). The same also happened to corns which decreased from 4,069 tons in 2007 to only 450 tons in 2011 (Badan Statistik Kabupaten Belu 2012). The same was also found in the District of East Kobalima. According to "Kobalima dalam Angka" the yield of rice decreased from 4067 in 2007 to only 1,876 in 2011 (Badan Pusat Statistik Kabupaten Belu 2012). The Disctrict of Raihat showed different numbers, even though not quite significant. According to "Raihat dalam Angka", the yield of rice decreased from 2,832 tons in 2007 to 3,128 tons in 2011. As for corns, it decreased from 4.069 tons in 2007 to 4,255 tons in 2011 (Badan Pusat Statistik Kabupaten Belu 2012). 
From the same source, we also found out that the size of the productive land was getting smaller as shown in Raihat, from 5,264 ha in 2007 to $3,305.25$ ha in 2011. As for East Tasifeto, it decreased from 5,127 ha in 2007 to 1,028 ha in 2011. Unfortunately, the numbers are not recorded in East Kobalima (Badan Pusat Statistik Kabupaten Belu 2012). This decrease clearly affects the people's income and their welfare and it is worsened by the fact that industries are not developing yet. In Raihat, there are only non-formal industries like rice mills, the industries of banana and sweet potato crackers, weavings, and potteries with the total number of which is only 108 in 2011 and they only employ as many as 180 workers. In East Tasifeto, there are only 64 weaving industries that employ as many as 128 workers. As for East Kobalima, there are as many as 30 industries that employ as many as 60 workers (Badan Pusat Statistik Kabupaten Belu 2012). So, the minimum amount of land and the minimum number of formal and non formal industries have concomitantly hindered the people from getting their welfare.

The amount of the trading commodities is in fact small. They are dailyneed goods like noodles, tofu, tempe, fish, tins, and gasoline. Some sell one or two goats or buffalos. Motorbikes are also taken from Atambua to Timor Leste. Gasoline is the largest amount of all, for it makes the biggest profit. As said by a chief village in Silawan, the gasoline bought in Atambua for Rp. 5,500 would then be sold in Timor Leste for Rp. 17,000 per litre. The profit is big especially before the gasoline price raise from PERTAMINA (Interviews of Illegal Trading, 20-26 August 2013).

The people of Silawan and Mota'ain in a meeting of February 2013 with the Village chief of Silawan, Chief of the Local Police Office, Second Inspector Fritz Mada, and the Head of the Intelligence of the Task Force of the Border of LINUD 503 also acknowledged that they knew the smugglings. In the meeting, people argued that they did it to fulfill their daily needs because they did not have jobs. They would stop smuggling if the government would help make the better life of the people to meet the daily needs.

In addition to limited road facilities and water supply, this area also lacks electricity power supply. The electric company cannot meet the needs of households yet, let alone the needs for industries, not even for small industries. Consequently, the people feel being left behind, "date since the independence of Indonesia 68 years ago such infrastructures as roads, bridges, electricity, housing, and water have never been well provided for the people around the border. We have been deeply undergoing the situation; and we feel that independence is only for those living in Java" (Riyadi 2013). 
The booming of illegal trades is also facilitated by the absence of cross border market that should otherwise be provided by the government. According to an article, the market was closed because of the 2006 fishermen shooting incident by policemen (Koran Tempo, 2013). There used to be markets operating for some years, from 2003 to 2006 and As much as $200 \%$ profit margin could be gained. All kinds of goods were displayed there such as cigarettes, noodles, and also luxury cars (Interviews about Illegal Trading, 20-26 August 2013). Unfortunately, the government never inform the locals about the closures properly as two respondents said that "actually we wanted and expected to make use of the markets. But the markets were suddenly closed down. They were really beneficial for us as we could trade and we meet our daily needs." In addition, a respondent stated that "the people here actually really need the markets. We used to have some markets. Without any reason, the government suddenly closed the market. We didn't know what regulation was applied." (Interviews about illegal trading, 20-26 August 2013).

According to Belu Vice-regent, Ludovikus Taolin, since the central government built the markets in 2003, some of them have been located on the borders in Mota'ain (Indonesia)-Batugade (Timor Leste), Metamauk-Salele, Builalo-Memo, Haekesak-Turiskain, Laktutus-Belulik Leten. However, they have been inefficiently used. Those inter-state markets have not been optimally used because of some internal and external factors of the two countries' market managers, such as security issues. Also, The Timor Leste market managers have not been ready with the technical requirements of border-crossing pass issuance. This is due to the technical issues of PLB endorsement. According to an article, border crossing traders should be distinguished from ordinary citizens in buying and selling interactions (Kompas 2010.)

After the cross-border markets were closed down, some people used them for productive business and for fulfilling daily needs. At that time the government of Belu allowed the people to use the markets to fulfill their needs. Unfortunately, illegal levies were imposed in the markets so that since 2006 the markets were closed down again. In Memu, Lian Sorun, Maubusa and Malibaka markets, for instance, illegal levies as much as Rp. 10,000 to Rp. 20,000 were imposed to the market customers who were generally poor farmers.

Since 2006, there has been a lot of traditional trading since there is not any market around the border. Some people recklessly crossed the border in order to earn some money. In Turiskain, for example, the lack of markets, facilities and services, and the absence of roads or bridges to and from Timor Leste, have made some people cross the wide river in order to sell several goats. 
Seeing this condition, traditional markets are re-operated by the local government to help the people fulfill their needs. In an interview, a respondent explained that the market helps the people sell their merchandise or fulfill their basic needs so that they do not need to go to Atambua. In addition, the market provides a place for the farmers to sell their agricultural products. The traditional market also facilitates Timor Leste people to visit each other and to meet other needs.

Based on the border management concepts, this research proposes a model which emphasizes on the reorganizing of the security function (S/Security) by removing the military in Cross Border Post management. Thus, we change the $\mathbf{S}$ (capital letter $\mathbf{S}$ ) with s (lower case s). The fifth function that we add is $\mathbf{S}$ (Social Function).

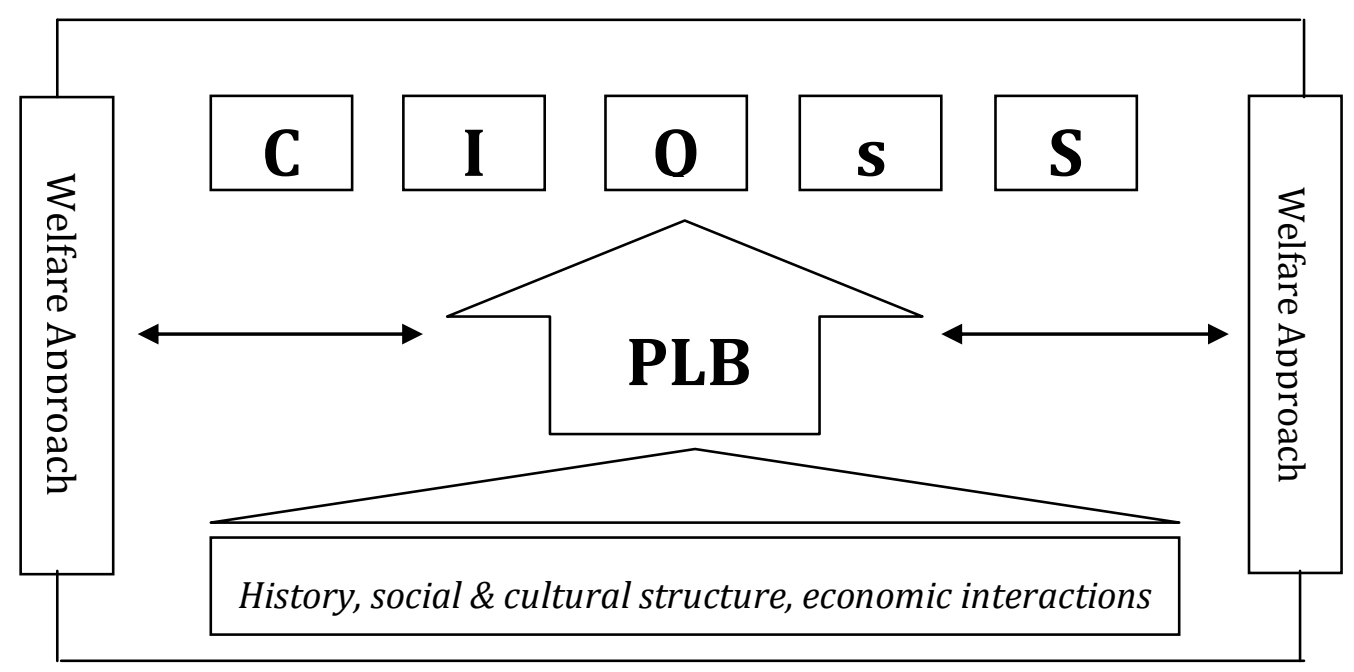

Picture 2. A Cross Border Post Model

This model proposes three important points. First, expanding the function of the Cross Border Post is needed. The function of CIQS which includes Customs, Immigration, Quarantine and Security has not been well performed due to the limited facilities. The existing facility really needs to be improved. The quality of the human resources also needs to be improved. The awareness of archiving is still low whereas recorded/written documents are important data for the policy makers in deciding steps for improvement and assessments of the Cross Border Post. 
Optimizing the function of customs is necessary, especially in improving the quality and the quantity of the existing facilities. Of the three Cross Border Posts which we studied, almost all of the posts do not provide sufficient facilities which support the role of a customs such as an office that controls goods to and from another country. The function of customs might be optimized by re-activating the cross border market in order to develop better local welfare.

The immigration authority should improve the ways of informing administration fees since our findings showed that there were a lot of people who didn't know how much they have to pay to get the red book (buku merah). Managing the border crossing pass is crucial due to the high social and economic needs to cross the borders between the countries. Nevertheless, the people's financial condition is not sufficient yet. The bad transportation facilities, the long distance to the regency make the passports and visas become expensive documents for the cross borders. Thus, the customs function can be optimized through managing border crossing pass and conducting transparent administration.

The quarantine function of health, animals, and plants at the three Cross Border Posts showed that this function also has not been well-operating. Moreover, the quarantine function in Motamasin and Turiskain did not even operate. Drug trafficking has started to disperse along the borderline. Therefore, it is urgent for the government to improve the health, animals, and plants quarantine services at all Cross Border Posts.

Second, re-conceptualizing the border security is required. The welfare approach should be prioritized. The border area is not a buffer zone which is isolated and guarded by military forces. We think that there is no more reason for security approach. Any problem arising in the border area is not a subversive and political one but a criminal offence driven by economic motives.

Third, in order to set the Social Function, we have to involve the local custom experts or tetua adat to helps local government settle the locals problems. For instance, about land issue, the Timor people in Indonesia might own land in Timor Leste and vise versa, the Timor people in Timor Leste might own land in Indonesia. However, land ownership is restricted by the state law jurisdiction and according to an article this might cause a problem (Tabloid Diplomasi 2011). They will be the representatives also to communicate their economy and social issues and become a bridge between governments and local peoples.

The cross border posts should carry the Social Function. This function will help the local government in the regency or village levels make the people comply with state border rules and enforce the applicable laws. 
This function disseminates all rules to make the people understand the importance of complying with the cross border rules by having a direct and personal contact. In addition, it is progressive in nature in finding out cross border problems and in gathering information concerning the people's needs upon the cross border post service. Thus, the cross border post is no longer a passive institution that only serves the cross borders by stamping documents and supervising their luggage but an institution that encourages the people's social and economic activities to become more valuable.

\section{Conclusion}

Our two years research which was supported by Direktorat Jenderal Pendidikan Tinggi through Hibah Bersaing Programe found that reorganising the $\mathrm{CPB}$ is necessary to be accorded with the social and historical backgrounds and also economy conditions. The military personel is no longer needed due to the changes of situation. The data found in Belu Police Force also showed that there were no subversive or political offences. Border offences were mainly of economic motives. The security function should therefore involve the Indonesia National Police to serve the people's needs and to ensure the safety of the people around the border and the cross borders.

To improve the previous function on the CIQS, the social function is essential to operate in the cross border posts in order to make this institution active in serving the cross borders' needs. Besides disseminating the border crossing rules, this function also polls the frontiers people's opinion on the needs which they feel should be provided in the border. It is important to perform this function since the distance between the frontier and the regency is pretty far. This function helps the local government manage the border area by accommodating the needs of the people around the border which include cross border trades and other socio-cultural interests.

\section{Acknowledgement}

This research was supported by Hibah Bersaing DIKTI "Model Pengelolaan Perbatasan Darat Indonesia-Timor Leste Melalui Optimalisasi Fungsi Pos Lintas Batas (PLB) di Kabupaten Belu, Nusa Tenggara Timur" 2013 and 2014. 


\section{References}

Aniszewski, Stefan. 2009. "Coordinated Border Management". World Custom Organizations. WCO Working Paper No. 2. http://www.wcoomd.org/en/topics/research/activities-andprogrammes/ /media/o7A938BoE7E74757BoDE18557FDF35BB. $\operatorname{ash} x$

Caflish, Lucius, 2006. "A Typology of Border", www.dur.ac.uk/resources/ibru/conferences/thailand/caflish.pdf

Hariyadi, 2008. "Pengelolaan Perbatasan Republik Indonesia (RI) Timor Leste (RDTL) dalam Perspektif Kebijakan Publik", dalam Kajian Vol. 13, No. 3, September, http://www.dpr.go.id/kajian/Pengelolaan-Perbatasan-Indonesia--Timor-Leste-dalam-Perspektif-Kebijakan-Publik-2008.pdf

Madu, Ludiro, Fauzan, dkk. 2010, Mengelola Perbatasan Indonesia du Dunia Tanpa Batas: Isu, Permasalahan dan Pilihan Kebijakan, Graha Ilmu, Yogyakarta.

Mc.William, Andrew dan Elizabeth G. Traube. 2011. Land and Life in Timor Leste Ethnograpich Essays. E Press: The Australian University University.

Pathak, Shreesh Kumar, 2001. "Concept of Border Management", http://jnu.academia.edu/ShreeshKumarPathak/Papers/139942/C oncept_of_Border_Management.

Polner, Maria, "Coordinated Border Management: from Theory to Practice", dalam World Customs Journal, Vol. 5, No. 2, www.worldcustomsjournal.org/media/wcj/-2011/2/polner.pdf.

Riyadi, Timur Arif. 2013. "Batas Negeri yang Suny”i. Jurnal Nasional. http://www.jurnas.com/halaman/12/2013-05-17/246773

Wuryandari, Ganewati, Keamanan di Perbatasan Indonesia-Timor Leste: Sumber Ancaman dan Kebijakan Pengelolaannya, Pustaka Pelajar, Yogyakarta, 2009.

"----, $\begin{aligned} & \text { "History } \\ & \text { http://pascal.iseg.utl.pt/ cesa/History_of_Timor.pdf }\end{aligned}$
October 13, 2015]. 


\section{Goverment Publications}

Badan Pusat Statistik Kabupaten Belu. 2012. "Kobalima Timur dalam Angka”. Katalog BPS : 1403.5306041.

Badan Pusat Statistik Kabupaten Belu. 2012. Raihat dalam Angka.2012. Katalog BPS : 1403.5306071.

Badan Pusat Statistik Kabupaten Belu. 2012.Tasifeto

Timur dalam Angka. 2012. Katalog BPS :

1403.5306070.

Kementrian Dalam Negeri. "Profil Kabupaten Belu". http://www.kemendagri.go.id/pages/profildaerah/kabupaten/id/53/name/nusa-tenggaratimur/detail/5304/belu, Kabupaten Belu dalam Angka, 2012.

\section{Online resources}

Hanoin, Mahein Nia 2011. "Postur Pertahanan Indonesia di Wilayah Perbatasan Timor Leste", , No. 1, 11 Maiu, 2011, fundasaunmahein.files.wordpress.com [accessed October 2, 2015]

Kompas.com, 2010. "Pasar Perbatasan dengan Timor Leste Terbengkalai”.

http://regional.kompas.com/read/2010/07/24/17473857/Pasar.P erbatasan.dengan.Timor.Leste.Terbengkalai

Koran Tempo.co, 2006. "Insiden Penembakan Warga Negara Indonesia di Perbatasan Timor Leste".

http://koran.tempo.co/konten/2006/o1/13/60568/InsidenPenembakan-Warga-Negara-Indonesia-di-Perbatasan-TimorLeste

Tabloid Diplomasi, 2011. "Masalah Di Perbatasan Timor Leste Perlu Pendekatan Hukum Adat". Tabloid Diplomasi Edisi Juli 2011. 